\title{
Biochemical and Toxicological Studies of Bridelia micrantha [Berth] and Mitracarpus villosus [Swartz] DC Extracts used as Biofumigant Against Stored Produce Insect Pests on Albino Rats
}

\section{Jacobs Mobolade Adesina*1(i), Thomas Inomisan Ofuya 2 (iD), Kayode David Ileke 3 (iD),Yallappa Rajashekar $^{4}$ (D), Titilayo Elizabeth Mobolade-Adesina ${ }^{5}$ (iD}

${ }^{1}$ Department of Crop, Soil and Pest Management Technology, Rufus Giwa Polytechnic, Owo, Ondo State, Nigeria.

${ }^{2}$ Department of Crop, Soil and Pest, Federal University of Technology, P. M. B. 704, Akure, Ondo State, Nigeria.

${ }^{3}$ Department of Biology, Federal University of Technology, P. M. B. 704, Akure, Ondo State, Nigeria.

${ }^{4} \mathrm{PhD}$ of Biotechnology, Institute of Bioresources and Sustainable Development, Insect Ecology Laboratory, Takyelpat, Imphal, India.

${ }^{5}$ Department of Science Laboratory Technology, Rufus Giwa Polytechnic, Owo, Ondo State, Nigeria.

\begin{tabular}{ll}
\hline Article Info & A B S T R A C T \\
\hline $\begin{array}{l}\text { Article Type: } \\
\text { Research }\end{array}$ & Background: \\
\hline $\begin{array}{l}\text { Article History: } \\
\text { Received: } 22.06 .2019\end{array}$ & In recent years, plant materials have been widely explored as sources of insect \\
Accepted: 08.10 .2019 & pest control agents with little or no study on their toxicity. The present study \\
& aimed to detect the biochemical alterations in liver and kidney associated with \\
& acute oral toxicity of the extracts of B. micrantha and $M$. villosus in albino rats.
\end{tabular}

\section{Methods:}

* Corresponding Author: Jacobs Mobolade Adesina

Department of Crop, Soil and Pest Management Technology, Rufus Giwa Polytechnic, P. M. B. 1019, Owo, Ondo State, Nigeria.

E-mail:moboladesina@rugipo.edu.ng

Twenty seven albino rats, weighing between 150-180g were used and divided into nine groups of three rats each, administered with different doses of each extracts $(0,500,1000,1500$ and $2000 \mathrm{mg} / \mathrm{kg})$. The plasma and homogenates of liver and kidney of the rats were investigated for the activities of alanine aminotransferase (ALT), aspartate aminotransferase (AST), alkaline phosphatase (ALT), total protein, urea and creatinine, using standard laboratory kits.

\begin{abstract}
Results:
The administration of either extract did not cause death or any hazardous symptoms of acute toxicity, nor resulted in any evident changes in the body weight. However, the extracts caused significant decreases in the levels of ALT, AST, ALP and total protein, urea and creatinine in biochemical parameters. They also caused a significant decrease in the serum parameters of treated rats' liver and kidney at all doses.
\end{abstract}

\section{Conclusions:}

The results demonstrated that the oral administration of B. micrantha ethyl acetate extract and of $M$. villosus petroleum ether extract may be considered as moderately free of toxicity. This was based on our findings that two compounds were moderately safe with respects to their effects on the liver and kidney functions at concentrations of up to $2000 \mathrm{mg} / \mathrm{kg}$ body weight of the rats.

Keywords:

Biochemical Agent; Creatinine; Extracts; Homogenates; Plasma; Serum

How to cite this paper:

Adesina JM, Ofuya TI, Ileke KD, Rajashekar Y, Mobolade-Adesina TE. Biochemical and Toxicological Studies of Bridelia micrantha [Berth] and Mitracarpus villosus [Swartz] DC Extracts used as Biofumigant Against Stored Produce Insect Pests on Albino Rats. Iran J Toxicol. 2019;13(4):5-10

\section{INTRODUCTION}

Plant materials, as sources of bioactive compounds, play a leading role in controlling insect pests since old times in the Tropical and Subtropical continent of the world. Pesticide residues, environmental and health challenges associated with the adoption of synthetic insecticides have rekindled interest in plant derived natural insecticides as potential replacements for synthetic agents. Various plant products have offered numerous biological activities like antibacterial, antifungal and anti-insect activities.

B. micrantha (Family: Euphorbiaceae) and Mitracarpus villosus (Sw) DC (Family: Rubiaceae) are indigenous medicinal plant species in Nigeria and are used traditionally in the treatment of some aliments $(1,2)$. These plants also possess insecticidal activities against 
Sitophilus zeamais, Podagrica uniforma, Dysdercus superstitious, and malaria vectors ( $\underline{3-7})$.

With the growing interests in the application of plant materials in the management of insect pests and coupled with the reported medicinal properties and insecticidal activity of certain plants, there is an urgent need for conducting scientific studies on their potential toxicities.

Liver is the principal site of the conversion and cleansing of xenobiotics, and; therefore, is expressly susceptible to these agents (요). Similarly, kidneys, as the major organs for the elimination of xenobiotics and the metabolites, are particularly predisposed to their harmful effects ()ㅡ. Damage to these organs often results in rises in the clinical biochemical parameters, such as serum liver enzymes: AST, ALT and ALP, and total protein, and urea and creatinine, as markers of the impairment of renal functions $(\underline{10})$. Adebayo et al. ( $\underline{11})$ and Anthonio et al. (12) have reported that AST, ALT and ALP levels in tissues and blood are important marker enzymes, used to assess the integrity of cell membrane, cytosolic activity and cell death in various organs.

This study was designed to investigate the biochemical alterations in rats' liver and kidneys secondary to the acute oral toxicity of $B$. micrantha ethyl acetate and $M$. villosus petroleum ether extracts, used as biofumigant against the effect of stored product insect pests on albino rats.

\section{MATERIALS AND METHODS}

\section{Collection of Plant Materials and Preparation of}

Extracts: Leaves of $B$. micrantha and M. villosus plants were collected from Rufus Giwa Polytechnic, Owo Ondo State, Nigeria. The plant materials were identified at the Department of Forestry and Wood Technology, Rufus Giwa Polytechnic, Owo, Ondo State, Nigeria (Latitude $7^{\circ} 11^{\prime} \mathrm{N}$ and Longitude $5^{\circ} 35^{\prime} \mathrm{E}$ ) were a specimen voucher was issued. The leaves were washed in clean water to remove dirt and dried in shade at room temperature for two weeks. To avoid volatilization, the materials were pulverized using electric blender (Binatone model; Japan) and packaged in a polythene bag until used.

Two hundred grams $(200 \mathrm{~g})$ of the plant powder was sequentially extracted with a series of solvents in order of increasing polarity viz., petroleum ether, hexane, ethyl acetate, acetone, chloroform and methanol, using Soxhlet apparatus (India). The solvents were removed using rotary vacuum evaporator under reduced pressure at $60^{\circ} \mathrm{C}$. The residue was dissolved in a known volume of methanol and assessed for insecticidal potential by fumigant toxicity. The active extract which showed maximum effect, was evaluated for the biochemical and toxicological activity in albino rats.

Experimental Animals: The 27 healthy, adult albino rats weighing between 150-180g were housed in cages under ambient environmental conditions of alternating $12 \mathrm{~h}$ light/dark cycles with free access to rat food and clean water ad libitum. The animals were acclimatized for a period of two weeks before the starting the study. All animals were handled according to the standard

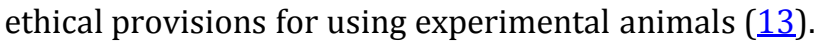

Experimental Design and Acute Toxicological Tests: After acclimatization, animals were arranged in a completely randomized order, comprising three rats per experimental and control groups with free access to food and water ad libitum as follows:

Group I: Control rats.

Group II: Rats treated with $500 \mathrm{mg} / \mathrm{kg}$ B. micrantha ethyl acetate extract

Group III: Rats treated with $1000 \mathrm{mg} / \mathrm{kg}$ B. micrantha ethyl acetate extract

Group IV: Rats treated with $1500 \mathrm{mg} / \mathrm{kg}$ B. micrantha ethyl acetate extract

Group V: Rats treated with $2000 \mathrm{mg} / \mathrm{kg}$ B. micrantha ethyl acetate extract

Group VI: Rats treated with $500 \mathrm{mg} / \mathrm{kg}$ M. villosus petroleum ether extract

Group VII: Rats treated with $1000 \mathrm{mg} / \mathrm{kg}$ M. villosus petroleum ether extract

Group VIII: Rats treated with $1500 \mathrm{mg} / \mathrm{kg}$ M. villosus petroleum ether extract, and

Group IX: Rats treated with $2000 \mathrm{mg} / \mathrm{kg}$ M. villosus petroleum ether extract.

Doses of each extract were administered through oral cannula to protect the oral cavity from being injured. All of the experimental animals were separately observed for mortality or signs of toxicity throughout the experiments.

Biochemical Analysis: At the end of the experimental period, the final body weights of the animals were measured and were then sacrificed by cervical decapitation after an overnight fast. The blood samples were centrifuged at 3000rpm for $5 \mathrm{~min}$. and the supernatants (plasma) were separated. The liver and kidneys homogenates were centrifuged at 2000rpm for 15 minutes and the supernatants (serum) were stored at $-20^{\circ} \mathrm{C}$ until they were used for the biochemical analyses (14). The plasma and sera from the homogenates of liver and kidneys were tested for the levels of alanine aminotransferase (ALT), aspartate aminotransferase (AST), alkaline phosphatase (ALT), total protein, urea, and creatinine, using standard laboratory kits (Randox, UK). The biochemical activities were measured following standard laboratory assays and procedures (15-16).

Statistical Analyses: The data thus obtained were statistically analysed by one-way analysis of variance (ANOVA) and significant treatment means were separated at $(\mathrm{p}<0.05)$, using the Tukey's multiple regression tests. Treatment data were presented as the means \pm standard error of the mean (SEM).

\section{RESULTS}

Effect of B. Micrantha and M. Villosus Extracts on Body Weight: There was no observed significant differences ( $p>0.05)$ among the experimental groups 
versus the control with respect to the body weight gain in rats administered with various dosages of $B$. micrantha ethyl acetate and $M$. villosus petroleum ether extracts (Table 1). Although, rats administered with $1000 \mathrm{mg} / \mathrm{kg} \mathrm{M}$. villosus extract had the least body weight gains $(0.85 \%)$. Also, irrespective of the extract dosages, no signs of behavioral changes, mortality or morbidity were observed throughout the study groups. Based on the data, it was evident that high concentrations of either extracts $(2000 \mathrm{mg} / \mathrm{kg})$ were not lethal to the rats.

Table 1. Effect of B. micrantha and M. villosus extracts on body weight of Albino rats

\begin{tabular}{cccc}
\hline Treatment Group & $\begin{array}{c}\text { Initial } \\
\text { weight (g) }\end{array}$ & $\begin{array}{c}\text { Final } \\
\text { weight (g) }\end{array}$ & $\begin{array}{c}\text { \% Weight } \\
\text { gain }\end{array}$ \\
\hline I & 178.34 & 181.48 & 1.76 \\
II & 169.51 & 173.03 & 2.07 \\
III & 172.07 & 175.67 & 2.09 \\
IV & 167.92 & 170.04 & 1.26 \\
V & 170.40 & 172.68 & 1.34 \\
VI & 171.41 & 173.37 & 1.14 \\
VII & 169.77 & 171.22 & 0.85 \\
VIII & 173.55 & 175.86 & 1.33 \\
IX & 171.09 & 174.82 & 2.18 \\
\hline
\end{tabular}

Each value is the mean for 3 rats per group.

Liver Biochemical Indices: The result of the biochemical effects of $B$. micrantha and M. villosus extracts on albino rats indicated that the responses were does-dependent. The levels of AST, ALT, ALP and total protein decreased with increasing the extracts doses (Table 2). Rats administered with $500 \mathrm{mg} / \mathrm{kg}$ of the extracts showed the highest biochemical activities, while those treated with $2000 \mathrm{mg} / \mathrm{kg}$ had the lowest values. However, AST, ALT, and ALP at dose of $2000 \mathrm{mg} / \mathrm{kg}$ showed significantly different activity compared with those noted in the control group $(\mathrm{p}<0.05)$. No significant differences were detected between doses at $500 \mathrm{mg} / \mathrm{kg}$ and $1000 \mathrm{mg} / \mathrm{kg}$. The total protein concentration had a significant reduction compared to those for the control group at all doses $(\mathrm{p}<0.05)$.

\section{Toxicity of B. Micrantha and M. Villosus Extracts on Serum Biochemical Parameters: Serum levels of AST, ALT and ALP in rats administered with varying doses of $B$. micrantha and $M$. villosus extracts are presented in Table 3. The result showed that the serum levels progressively and significantly $(\mathrm{p}<0.05)$ increased with the increasing dosages of the extracts. Rats treated with $2000 \mathrm{mg} / \mathrm{kg}$ showed the maximum levels of the liver enzymes. However, in spite of the increases in the serum levels of all treated rats, insignificant increases were noted in the groups treated with 500 and $1000 \mathrm{mg} / \mathrm{kg}$ compared to those in the control group.}

Table 2. Toxicity of B. micrantha and M. villosus extracts on some Liver Biochemical Indices of Albino Rats.

\begin{tabular}{|c|c|c|c|c|}
\hline $\begin{array}{l}\text { Plant Extracts/ } \\
\text { Conc. (ml) }\end{array}$ & $\begin{array}{c}\text { Aspartate aminotransferase } \\
\text { (AST) IU/g }\end{array}$ & $\begin{array}{c}\text { Alanine aminotransferase } \\
\text { (ALT) IU } / g\end{array}$ & $\begin{array}{c}\text { Alkaline phosphatase } \\
\text { (ALP) IU/g }\end{array}$ & $\begin{array}{c}\text { Total protein } \\
\min \left(\times 1^{-1}\right)\end{array}$ \\
\hline \multicolumn{5}{|l|}{$500 \mathrm{mg} / \mathrm{kg}$} \\
\hline B. micrantha & $170.25 \pm 4.20^{\mathrm{b}}$ & $122.50 \pm 1.11^{\mathrm{b}}$ & $28.50 \pm 1.11^{\mathrm{b}}$ & $1.62+0.01^{b}$ \\
\hline M. villosus & $165.25 \pm 4.20^{\mathrm{b}}$ & $117.50 \pm 2.11^{\mathrm{b}}$ & $22.00 \pm 1.11^{\mathrm{b}}$ & $1.53 \overline{+0.02^{b}}$ \\
\hline \multicolumn{5}{|l|}{$1000 \mathrm{mg} / \mathrm{kg}$} \\
\hline B. micrantha & $163.25 \pm 4.20^{\mathrm{b}}$ & $116.50 \pm 2.10^{\mathrm{b}}$ & $28.50 \pm 1.10^{\mathrm{b}}$ & $1.50 \underline{0} .02^{\mathrm{b}}$ \\
\hline M. villosus & $162.00 \pm 4.21^{\mathrm{b}}$ & $115.00 \pm 2.21^{\mathrm{b}}$ & $22.00 \pm 1.11^{\mathrm{b}}$ & $1.50+0.04^{b}$ \\
\hline \multicolumn{5}{|l|}{$1500 \mathrm{mg} / \mathrm{kg}$} \\
\hline B. micrantha & $148.50 \pm 4.10^{\mathrm{a}}$ & $102.75 \pm 2.28^{\mathrm{a}}$ & $10.75 \pm 1.08^{a}$ & $0.80+0.03^{a}$ \\
\hline M. villosus & $143.75 \pm 4.28 \mathrm{a}$ & $107.25 \pm 2.20^{\mathrm{a}}$ & $9.00 \pm 1.10^{\mathrm{a}}$ & $0.80+0.03^{a}$ \\
\hline \multicolumn{5}{|l|}{$2000 \mathrm{mg} / \mathrm{kg}$} \\
\hline B. micrantha & $146.25 \pm 4.20^{\mathrm{a}}$ & $100.50 \pm 2.10^{\mathrm{a}}$ & $9.25 \pm 1.10^{\mathrm{a}}$ & $0.75+0.02^{\mathrm{a}}$ \\
\hline M. villosus & $137.25 \pm 4.20^{\mathrm{a}}$ & $100.50 \pm 2.10^{\mathrm{a}}$ & $8.75 \pm 1.14^{\mathrm{a}}$ & $0.70+\underline{0.02^{\mathrm{a}}}$ \\
\hline Untreated & $172.75 \pm 2.17^{b}$ & $125.25 \pm 2.20^{\mathrm{ab}}$ & $28.50 \pm 1.11^{\mathrm{b}}$ & $1.64+0.01^{b}$ \\
\hline
\end{tabular}

Each value is the mean \pm standard error for three replicates. Mean in the same column with the similar superscripts are not significantly different at $(\mathrm{p}<0.05)$ using the New Duncan's Multiple Range Test.

Table 3. Toxicity of B. micrantha and M. villosus extracts on some serum biochemical parameters of Albino rats

\begin{tabular}{|c|c|c|c|}
\hline $\begin{array}{l}\text { Plant Extracts/ } \\
\text { Conc. }(\mathrm{mg} / \mathrm{kg}) \\
\end{array}$ & $\begin{array}{c}\text { Aspartate aminotransferase } \\
\text { (AST) IU/g }\end{array}$ & $\begin{array}{c}\text { Alanine aminotransferase (ALT) } \\
\mathrm{IU} / \mathrm{g}\end{array}$ & Alkaline phosphatase (ALP) IU/g \\
\hline \multicolumn{4}{|c|}{$500 \mathrm{mg} / \mathrm{kg}$} \\
\hline B. micrantha & $48.50+2.10^{\mathrm{a}}$ & $40.25+2.20^{\mathrm{a}}$ & $24.00+1.10^{\mathrm{a}}$ \\
\hline M. villosus & $49.50+2.10^{\mathrm{a}}$ & $45.50 \pm 2.10^{\mathrm{a}}$ & $27.25+1.20^{\mathrm{a}}$ \\
\hline \multicolumn{4}{|c|}{$1000 \mathrm{mg} / \mathrm{kg}$} \\
\hline B. micrantha & $52.00 \pm 2.10^{\mathrm{a}}$ & $47.00 \pm 2.10^{\mathrm{a}}$ & $25.25 \pm 1.20^{\mathrm{a}}$ \\
\hline M. villosus & $55.25+2.20^{\mathrm{a}}$ & $48.25+2.20^{\mathrm{a}}$ & $29.25+1.20^{\mathrm{a}}$ \\
\hline \multicolumn{4}{|c|}{$1500 \mathrm{mg} / \mathrm{kg}$} \\
\hline B. micrantha & $68.00 \pm 2.10^{\mathrm{b}}$ & $60.25 \pm 2.20^{b}$ & $40.00 \pm 2.10^{b}$ \\
\hline M. villosus & $76.00+2.10^{\mathrm{b}}$ & $71.50+2.10^{\mathrm{b}}$ & $40.50+1.15^{b}$ \\
\hline \multicolumn{4}{|c|}{$2000 \mathrm{mg} / \mathrm{kg}$} \\
\hline B. micrantha & $88.50 \pm 2.15^{c}$ & $83.00 \pm 2.10^{c}$ & $56.50 \pm 2.15^{c}$ \\
\hline M. villosus & $89.25+2.20^{c}$ & $88.00 \pm 2.10^{c}$ & $60.00 \pm 2.10^{c}$ \\
\hline Untreated & $45.00+2.21^{a}$ & $38.50+2.10^{\mathrm{ab}}$ & $19.00+1.11^{b}$ \\
\hline
\end{tabular}

Each value is the mean \pm standard error for three replicates. Means in the same columns with similar superscripts are not significantly different at $(\mathrm{p}<0.05)$ using the New Duncan's Multiple Range Test. 


\section{Toxicity of B. Micrantha and M. Villosus Extracts on the Kidney Biochemical Parameters: The} administration of $B$. micrantha and $M$. villosus extracts was associated with changes in kidney biochemical serum parameters (Tables 4 and 5). The data showed a significant dose-dependent response in treated rats compared to the control group $(\mathrm{p}<0.05)$.

Table 4. Toxicity of B. micrantha and $M$. villosus Extracts on some Kidney Biochemical Parameters of Albino Rats.

\begin{tabular}{ccc}
\hline $\begin{array}{c}\text { Plant Extracts/ } \\
\text { Conc. (mg/kg) }\end{array}$ & Urea (mmol/l) & Creatinine (mmol/l) \\
\hline & $500 \mathrm{mg} / \mathrm{kg}$ & \\
B. micrantha & $31.00 \pm 2.10^{\mathrm{b}}$ & $164.25 \pm 3.20^{\mathrm{b}}$ \\
M. villosus & $29.00 \pm 2.10^{\mathrm{b}}$ & $157.50 \pm 3.15^{\mathrm{b}}$ \\
\hline & $1000 \mathrm{mg} / \mathrm{kg}$ & \\
B. micrantha & $25.25 \pm 2.20^{\mathrm{b}}$ & $159.00 \pm 3.10^{\mathrm{b}}$ \\
M. villosus & $24.25 \pm 2.20^{\mathrm{b}}$ & $153.00 \pm 3.10^{\mathrm{b}}$ \\
\hline & $1500 \mathrm{mg} / \mathrm{kg}$ & \\
B. micrantha & $20.00 \pm 2.10^{\mathrm{a}}$ & $132.25 \pm 3.20^{\mathrm{a}}$ \\
M. villosus & $19.50 \pm 2.15^{\mathrm{a}}$ & $126.50 \pm 3.15^{\mathrm{a}}$ \\
\hline & $2000 \mathrm{mg} / \mathrm{kg}$ & \\
B. micrantha & $18.50 \pm 2.15^{\mathrm{a}}$ & $127.00 \pm 3.10^{\mathrm{a}}$ \\
M. villosus & $17.25 \pm 2.20^{\mathrm{a}}$ & $123.25 \pm 3.20^{\mathrm{a}}$ \\
\hline Untreated & $33.50 \pm 2.15^{\mathrm{a}}$ & $166.25 \pm 3.20$ \\
\hline
\end{tabular}

Each value is the mean \pm standard error for three replicates. Means followed by the same letter

along the column are not significantly different $(\mathrm{P}>0.05)$, using New Duncan Multiple Range Test.

Table 5. Toxicity of B. macrantha and M. villoscus Extracts on some Serum Biochemical Parameters of Albino Rats.

\begin{tabular}{|c|c|c|}
\hline $\begin{array}{l}\text { Plant Extracts/ } \\
\text { Conc. (mg/kg) }\end{array}$ & Urea (mmol/l) & $\begin{array}{l}\text { Creatinine } \\
\text { (mmol/l) }\end{array}$ \\
\hline \multicolumn{3}{|l|}{$500 \mathrm{mg} / \mathrm{kg}$} \\
\hline B. macrantha & $16.00 \pm 1.10^{a}$ & $51.50 \pm 2.15^{\mathrm{a}}$ \\
\hline M. villoscus & $19.25 \pm 1.20^{\mathrm{a}}$ & $53.25 \pm 3.20^{a}$ \\
\hline \multicolumn{3}{|l|}{$1000 \mathrm{mg} / \mathrm{kg}$} \\
\hline B. macrantha & $19.50 \pm 2.15^{\mathrm{a}}$ & $54.00 \pm 2.10^{\mathrm{a}}$ \\
\hline M. villoscus & $24.00 \pm 1.10^{\mathrm{a}}$ & $55.50 \pm 2.15^{a}$ \\
\hline \multicolumn{3}{|l|}{$1500 \mathrm{mg} / \mathrm{kg}$} \\
\hline B. macrantha & $44.00 \pm 2.10^{\mathrm{b}}$ & $89.50 \pm 2.15^{b}$ \\
\hline M. villoscus & $45.25 \pm 2.20^{\mathrm{b}}$ & $91.00 \pm 2.10^{\mathrm{b}}$ \\
\hline \multicolumn{3}{|l|}{$2000 \mathrm{mg} / \mathrm{kg}$} \\
\hline B. macrantha & $59.00 \pm 2.10^{c}$ & $114.50 \pm 3.15^{a}$ \\
\hline M. villoscus & $62.00 \pm 2.10^{\mathrm{a}}$ & $115.50 \pm 3.15$ \\
\hline Untreated & $13.25 \pm 1.20^{\mathrm{a}}$ & $45.00 \pm 2.10$ \\
\hline
\end{tabular}

Each value is the mean \pm standard error of three replicates. Means followed by the same letter.

\section{DISCUSSION}

B. micrantha and $M$. villosus have been shown to have insecticidal properties $(5,7)$ suggesting that they could be used for the development of new chemical compounds for the management of insect pests. In spite of its efficacy, there are growing concerns about the toxicity of plant products in last decade due to their bioactive contents. However, few toxicological studies have been conducted to determine if the plants' bioactive molecules are safe, particularly if the primary intention is to protect food grains for human consumption.
The insignificant differences ( $p>0.05)$ noted in the body weight gain at the end of the experiments in all of the doses of extracts administered to the rats compared to those in the controls, suggest that the extracts were not lethal to the rats. This observation also suggests that the extract did not alter the metabolic processes of the treated rats, which might have subsequently affected the hormones and body weight (17). The observed increases in body weight could be attributed to the extracts' nutritional properties $(\underline{18})$ without significant alterations in the energy metabolism of the rats $(\underline{19})$. This is consistent with the findings reported by Oshomoh et al. (20) who showed that weight changes in rats orally administered with aqueous extract of $B$. micrantha were not significantly different between the control and the treated groups. Konate ( $\underline{21})$ also observed insignificant differences in weights and no other detectable clinical signs in rats treated with the aqueous and acetone extracts of Cienfuegosia digitate.

Liver is a vital organ actively involved in many metabolic and biochemical processes, and is the frequent target for many toxins (22). Hepatic damages are linked to alterations in the metabolic functions of this organ (23). Renal and hepatic function analyses are very useful for the screening of the toxicity of drugs and plant extracts, as both are important for the survival of an organism (24). Our data revealed that the extracts mildly impaired the kidney functions in the treated rats since the given doses slightly increased the levels of urea and creatinine.

The increase in ALP level suggests the likelihood of the extracts at high concentrations caused cell membrane damage in the liver. However, increased ALP activity is needed during stress to produce adequate amount of phosphate groups for oxidative phosphorylation leading to ATP generation. This in turn, is required for the phosphorylation of some biomolecules, such as ethanolamine and choline to form phosphatidyl ethanolamine and choline, which are vital to the stability of cellular plasma membrane (11). Apart from the significant decreases and increases in AST, ALT and ALP levels in the liver and serum biochemical indices, no deviation of these parameters was detected in rats treated with various doses of the extracts. Consequently, liver impairment did not occur in rats, which further suggests that both extracts were most likely safe. The lack of adverse effect of $B$. micrantha and $M$. villosus extracts on renal function indices in rats may suggest that the typical functioning of the nephrons at the glomeruli level was not affected.

When administered at a dose of $2000 \mathrm{mg} / \mathrm{kg}$, the extracts caused either significant increases or decreases in the levels of AST, ALT ALP and total protein in serum and liver biochemical parameters, respectively. This is consistent with the findings of

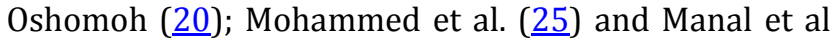
$(\underline{26})$ who reported a similar trend in rats administered with the aqueous extract of $B$. micrantha, butanol fraction of Buchholzia coricea and ethyl acetate extracts of Maerua psuedopetalosa. 
Protein is crucial for growth and replacement of wornout tissues. The rate of cell divisions is determined chiefly by the rate of protein synthesis (27). Serum or plasma is a very complex mixture of proteins and their determination is clinically valuable, which reveals the systemic and biochemical status of the individual. The decline in total proteins $(\mathrm{p}<0.05)$ in this study suggests that the extracts reduced the liver's synthetic capacity for proteins in rats treated with $B$. micrantha ethyl acetate and $M$. villosus petroleum ether extracts compared to those in the control rats. This corroborate the findings of Atere and Ajoa (28) who reported a decreasing trend in serum total proteins in rats administered with the crude alkaloidal fraction of Gnestis ferruginea roots. These results also suggest liver impairment secondary to the plant extract treatments (29). Dhanotiya (무) believes that liver damage decreases plasma protein, which might be the result of a decline in the protein absorption from the small intestine (31), which is also considered as a sign of impaired synthetic function of the liver. The lower the doses of extracts, the higher were the urea and creatinine activities of the kidney biochemical parameters. In the serum, the higher the extract doses, the higher were the urea and creatinine levels. In this study, increased serum urea was documented in treated animals. This may indicate impaired renal function due to the adverse effects of the extracts. This is consistent with the findings of Tanuja et al. ( $\underline{32})$. Serum urea level differs directly with protein intake and inversely with the rate of excretion. Creatinine is the waste product formed in the muscles by its metabolism and is synthesized in the liver, passes into the circulation and is taken up almost entirely by the skeletal muscles (3ㅡ). An increase in the creatinine level may indicate the renal damage, and increase in serum creatinine reflects the extent of tubular necrosis (34). Generally, our results suggest that the toxicity of both extracts against serum and biochemical parameters is dose dependent. This is consistent with the findings of Poonkodi, et al. ( $\underline{35})$ who reported that the anti-inflammatory effect of $M$. villosus extract was dose dependent.

\section{CONCLUSIONS}

The findings of this study revealed that ethyl acetate and petroleum ether extracts of $B$. micrantha and $M$. villosus had mild to moderate effects on the treated rats. The extracts slightly increased and reduced the levels of biochemical and serum parameters linked to the liver and kidney functions, respectively. Therefore; our findings may suggest that both extracts exerted mild toxicity effects. However, for the ultimate safety, future investigations on the genotoxicity, mutagenesis and reproductive toxicity are recommended to elucidate the adverse effects of the extracts evaluated in this study.

\section{ACKNOWLEDGEMENTS}

The authors wish to acknowledge the financial support by the Third World Academy of Science (TWAS) under
Research and Training Fellowship. We are also grateful to the Institute of Bioresources and Sustainable Development (IBSD), Manipur, India, for providing the laboratory facilities needed to conduct this study.

\section{CONFLICT OF INTERESTS}

The authors declare no conflict of interests in the course of conducting this study.

\section{REFERENCES}

1. Omeh YN, Onoja SO, Ezeja MI, et al. Subacute antidiabetic and in vivo antioxidant effects of methanolic extract of Bridelia micrantha (Hochst Baill) leaf on alloxan-induced hyperglycaemic rats. Journal of Complementary and Integrative Medicine. 2014;11:99-105.

2. Nwaehujor CO, Igile GO, Ode JO, et al. Anti-Inflammatory activities of methanol leaf extract of Bridelia micrantha (Hochst) Baill (Euphorbiaceae) in wistar rats. Journal of Applied Pharmaceutical Science. 2014;5:68-73.

3. Jose AR, Adesina JM. Damage Suppression of Stored Maize (Zea mays) Infested by Maize Weevil (Sitophilus zeamais Motschulsky) using Bridellia micrantha and Chasmanthra dependens Leaves Powder. In Adediran JA, Saka J. O, Ibrahim A. G, Adenekan MO, Atere AO, Adeyemi VA. (eds). Revamping Nigerian Agriculture through Transformation Agenda: The way forward. Proceedings of 47th Annual Conference of Agricultural Society of Nigeria, held at Federal College of Animal Health and Production Technology, Ibadan, Nigeria, Nov. 4-8, 2013. pp 38-41.

4. Adesina JM, Ileke DK. Insecticidal Efficacy of Mitrocarpus villosus and Momordica charantia Extracts for the Control of Flea Beetles Podagrica spp. Jacq. (Coleoptera: Chysomelidae) on Okra Abelmoschus esculentus (L). Moench, Medicinal Plant Research. 2014;4(1):1-5.

5. Adesina JM, Ofuya TI, Rajashaker Y. Efficacy of some aqueous plant extracts against cotton stainer, Dysdercus superstitious (Herrich schaffer) (Hemiptera: Pyrrhocoridae). Journal of Entomology and Zoology Studies. 2016;4(4):170-174.

6. Adesina JM, Ofuya TI, Rajashekar Y, et al. Insecticidal Evaluation of Bridelia micrantha and Dalbergia lactea aqueous extracts for the control of Podagrica uniforma (Jacoby) and Nisotra dilecta (Jacoby) (Coleoptera: Chysomelidae) Infestation on Okra. Agrivita Journal of Agricultural Science. 2016;38(3):269-274.

7. Ileke KD, Adesina FP. Bioefficacy of Larvicidal and Pupicidal properties of Clerodendrum capitatum and Bridelia machrantha leaves extracts against Malaria Vector, Anopheles gambiae giles (Diptera: Culicidae). Journal of Biology and Medicine. 2018;2:007-011.

8. Sturgill MG, Lambert GH. Xenobiotic-induced hepatotoxicity: Mechanisms of Liver and methods of monitoring hepatic function. Clinical Chemistry. 1997;43:1512-1526.

9. Subcommittee on biologic Markers in Urinary Toxicology, Committee on Biologic Markers. Biologic Markers in Urinary Toxicology. National Academy Press, Washington DC, USA; 2002.

10. Ferguson, MA, Vaidya VS, Bonventre JV. Biomarkers of Nephrotoxic Acute Kidney Injury. Toxicology. 2008;245(3): 182-193. 
11. Adebayo AH, Aliyu R, Gatsing D, et al. The effects of ethanolic leaf extract of Commiphora Africana (Buseraceae) on lipid profile in rats. Intl. J. Pharmacology. 2006;2:618-622.

12. Anthonio OA, Roland NN. Phytochemical Analysis and antibacterial evaluation of the ethyl acetate extract of the stem back of Bridelia micrantha. Pharmocognosy Magazine. 2013;9(33):45-50.

13. National Institutes of Health. Committee for the Update of the Guide for the Care and Use of Laboratory Animals. Washington (DC): National Academies Press, USA. 2011.

14. Arun K, Balasubramanian U. Comparative Study on Hepatoprotective activity of Phyllanthus amarus and Eclipta prostrata against alcohol induced in albino rats. International Journal of Environmental Science. 2011;2:361-379.

15. Schumann GR, Bonora F, Ceriotti GF, et al. IFCC Primary reference procedures for the measurement of catalytic activity concentrations of enzymes at 37 degrees C. International Federation of Clinical Chemistry and Laboratory Medicine. Part 5. Reference procedure for the measurement of catalytic concentration of aspartate aminotransferase. Clinical Chemistry and Laboratory Medicine. 2002; 40: 725-733.

16. Abotsi, WK, Ainooson GK, Gyasi EB, et al. Acute and subacute toxicity studies of the ethanolic extract of the aerial parts of Hilleria latifolia (Lam.) H. Walt. (Phytolaccaceae) in rodents. West African Journal of Pharmacy. 2011;22:27-35

17. Cajuday AL, Poscidio LG. Effects of Moringa oleifera Lam: (Moringaceae) on the reproduction of male mice (Mus musculus). Journal of Medicinal Plants Research. 2010;4(12):1115-1121.

18. Ezeonwumelu JOC, Julius $\mathrm{AK}$, Muhoho $\mathrm{CN}$, et al. Biochemical and Histological Studies of Aqueous Extract of Bidens pilosa Leaf from Ugandan Rift Valley in Rats. British Journal of Pharmacology and Toxicology, 2011;2(6):302-309.

19. Christian AG, Kechi EL, Oshie NC, et al. Haematological and biochemical changes after exposure to Maerua crassifolia ethanol leaf extract in rats. Journal of Applied Pharmaceutical Science. 2017;7(6):136-140.

20. Oshomoh EO, Idu M, Uwaya D. Toxicity studies of aqueous extract of Bridelia micrantha stem administered to mice and rats. International Journal of Pharmaceutical Science Research. 2014;5(7): 2856-2865.

21. Konate $\mathrm{K}$, Souza A, Lamidi $\mathrm{M}$, et al. Biological and toxicological effects of aqueous acetone extract of Cienfuegosia digitata Cav. in mice and rats. Journal of Pharmacology and Toxicology. 2011;6(2): 149-157.
22. Meyer SA, Kulkarni AP. Hepatotoxicity. In: Introduction to biochemical toxicology. 3rd Ed. New York: John Wiley and Sons, 2011; p: 487.

23. Wolf PL. Biochemical diagnosis of liver diseases. Indian Journal of Clinical Biochemistry.1999;14: 59-90.

24. Olorunnisola OS, Bradley G, Afolayan AJ. Acute and subchronic toxicity studies of methanolic extract of Tulbaghia violacea rhizomes in Wistar rats, African Journal of Biotechnology. 2012;11: 14934-14940.

25. Mohamed TS, Maadhusudhana. S, Ramkanth V, et al. Hepatoprotective herbs a review. International Journal of Research in Pharmaceutical Sciences. 2010;1:1-5.

26. Manal AI, El Bushra EE, Ahmed AG. Changes in Body Weight and Serum Biochemical Parameters of Wistar Rats Orally Dosed with Maerua pseudopetalosa (Gilg and Bened.) De Wolf tuber extracts. European Journal of Research in Medical Science. 2016;4(1):52-59.

27. Baxter G, Stanners C. The Effect of Protein Degradation on Cellular Growth Characteristics. Journal of Cellular Physiology. 1987;96:139-145.

28. Atere T, Ajao, A. Toxicological implications of crude alkaloidal fraction from Gnestis ferruginea D. C. root for liver function indices of male Wistar rats. Intl. J. Biomed. and Healthcare Science. 2009; 5 (3),1189-1195.

29. Yakubu MT, Bilbis LS, Lawal, M. Akanji MA. Effect of repeated administration of sildenafil citrate on selected enzyme activities of liver and kidney of male albino rats. Nigeria Journal of Pure and Applied Science 2007; 18:1395-1400.

30. Dhanotiya R Textbook of Veterinary Biochemistry 2nd edition. Jaypee Brothers Medical Publishers Ltd, India: 2014; pp: 271-444.

31. Rolls $B$ The role of energy density in the over consumption of fat. J. Nutrition. 2000;130:268-271.

32. Tanuja S, Anjali S, Ravish K, et al. Acute toxicity study of Phyllanthus niruri and its effect on the cyto-architectural structure of nephrocytes in Swiss albino mice Musmusculus. Pharmacognosy Journal. 2016; 8:77-80.

33. Sottas PE, Kapke GF, Leroux JM. Adaptive bayesian approach to clinical trial renal impairment biomarker signal from urea and creatinine. Intl. J. Biological Science. 2013; 9(2):156-163.

34. Solez K. Pathogenesis of acute renal failure. Intl. Rev. Experimental Pathology.1982;24:277-333.

35. Poonkodi K, Vimala Devi K, Rubini M, et al. Evaluation of In vitro Anticancer and Anti-inflammatory Potential of Mitracarpus villosus (Sw) DC. Intl. J. Pharmacy. 2017;7(3):78-81. 